\title{
Linking Supervisor and Co-workers Support to Organizational Commitment: Mediating Effect of Work-Family Conflict
}

\author{
Himani Sharma ${ }^{1}$ and Varsha Yadav $\odot 1$, * \\ ${ }^{1}$ Haryana School of Business, Guru Jambheshwar University of Science and Technology, Hisar, India \\ * Corresponding author.
}

\begin{abstract}
The present study investigates the effect of supervisor support and co-worker support on employees' organizational commitment by incorporating the role of work-family conflict as a mediator. Primary data were collected from 353 employees working in the service sector of India. Partial least square structural equational modelling in Smart PLS software was used for analysis. Results confirm that supervisor support significantly influences the organizational commitment of the employees. Work-family conflict act as a mediator between the relationship of supervisor support and organizational commitment. There is no significant effect of co-worker support on organizational commitment. Work-family conflict does not mediate between the relationship of co-worker support and organizational commitment. This study explains the importance of supportiveness from the supervisor in an industrializing country like India. It also provides an insight to the management in realizing the need to provide sensitivity training to the supervisors and the fact that special attention should be given while hiring the supervisors. This research will be useful to the management, researchers, policymakers, and society at large.
\end{abstract}

Keywords: Supervisor support, Organizational commitment, Work-family conflict, Co-worker support

\section{Introduction}

Demographic, organizational and technological changes have made the work-family interface a relevant area to study. Balancing work and family have become a big challenge for the employees in the present times due to rising time demand and strain from both roles (Bhargava and Baral, 2009; Pradhan et al., 2016). Every person has to perform the role of a worker, spouse, parent, and caretaker of the elderly parents, and each role's performance requires time, commitment, and energy (Madhavi, 2015). Furthermore, very little time is left for the family due to the advent of MNC culture, where there is a never-ending competition, frequently mobile jobs and tours, long working hours, lesser leaves, increasing work pressure of meeting deadlines (Chandra, 2010; Aboobaker and Edward, 2019). Human resource is the most vital for attaining a competitive advantage in the present times (Murtza et al., 2020). Promised innovation, inventions, and efficient organization are possible only with a quality workforce (Kushwaha et al., 2020). A committed employee engages in behaviours that increase his value and support the organization (Zeinabadi, 2021). Such an employee is more likely to accept the goals and values and therefore is willing to put in more effort to achieve them and be a member of the organization. Every organization wants to increase its competitiveness in the organization using different means. Competitiveness helps bring down the cost and helps 
in achieving efficiency (Afshar Jahanshahi et al., 2020). Employees having a perception of high-level support feel obligated to remain with the organization so that they can reciprocate the favour to them (Limpanitgul et al., 2014). It is expected that positive attitudes lead to positive behaviour, which helps to achieve the organization's goals. Organizational commitment as a work attitude can significantly help an organization in achieving its goals (Bakhshi et al., 2011).

On the other hand, the work-family conflict has many negative consequences like job stress and dissatisfaction at the job (Sadiq, 2020). Therefore, it is essential to study both organizational commitment as well as work-family conflict. Supervisors act as workplace resources who can use different ways to successfully integrate work and family duties (Bhargava and Baral, 2009). Co-worker and supervisor support help in building employees' trust in their organization, which then manifests as organizational commitment (Yang et al., 2019). It was noticed that research regarding the significance of supervisor and co-worker support in increasing organizational commitment had got less attention as compared to family-friendly policies. A study conducted in Australian context clearly states that there are studies, which have studied direct relation between supervisor support and job satisfaction but could not find any study which has used work-family conflict as mediator between supervisor support and organization commitment (Tran et al., 2021). The detrimental influence of perceived work-family conflict (WFC) on employees' job-related attitudes has been studied in individualistic societies. However, in collectivist cultures, where the "family" is considered equally important, such a relationship must be investigated (Panda et al., 2021). Also, co-worker support in influencing organizational commitment is understudied. Therefore, the present study extends the existing research by including variables like co-worker support, organizational commitment and workfamily conflict as a mediator.

Also, studies using work-family conflict as a mediator are limited (Sadiq, 2020). To the best of our knowledge, such a paper is rare in the Indian context. Also, results of previous studies suggest that more attention needs to be given to supervisor support and co-worker support to enhance the use of formal practices such as family-friendly policies to manage inter-role conflict (Anderson et al., 2002; Talukder, 2019). Thus, our study tries to answer the following questions:

RQ1 Whether supervisor support helps in improving organizational commitment?

RQ2 Whether co-workers support helps in improving organizational commitment?

RQ3 To ascertain whether work-family conflict mediates the relationship between supervisor support, co-workers support, and organizational commitment?

\section{Literature Review}

The present study is based on the conservation of resources (COR) theory and the theory of social exchange, explaining why and how organizational commitment is influenced by supervisor and co-worker support. As workers believe in their organization's support for their family needs, they respond by being more attached to the organization (Allen, 2001). A supportive supervisor can take care of the employee's family needs by scheduling accordingly, helping employees in child care on corporate premises. They provide emotional or instrumental support, which reduces work-family conflict (Hammer et al., 2009). Also, positive work experience is created through support by evoking belongingness and loyalty, leading to affective commitment (Limpanitgul et al., 2014).

According to Hobfoll et al. (2000), Conservation of resource, model states that people try to build, keep and preserve resources, and they fear the loss of valuable resources (Kumar et al., 2019). Conservation of resource theory explains that when people experience stress, they make sure that there is minimum loss of resources. People will use whatever resources they have to cover up the gain or loss of resources or utilize resources from the environment. Thus, supervisor and co-worker support acts as a resource to the degree that it assists in preserving time, effort, energies, and other resources (Kumar et al., 2019).

\subsection{Theoretical Framework and Hypothesis}

Organizational commitment shows a mental agreement between employees and the organization (Bakhshi et al., 2011). It is the feeling for which employees work and the extent to which they identify themselves with the organizations (Bakhshi et al., 2011). Support from supervisors and co-worker provides a positive work experience, which influences employees to more emotionally connect with the organization (Rousseau and Aubé, 2010). Inability to fulfil personal responsibilities due to the job is considered work to family conflict (Gutek et al., 1991). The expectation of participation and maintaining a balance between job and family roles lead to work-life conflict (Karatepe and Kilic, 2007).

Supervisor and co-worker support perform an essential role in managing and reducing stress caused by workfamily conflict (Greenhaus and Parasuraman, 1994; Carlson and Perrewé, 1999). Supervisor support is the remedy that subordinates can use in work-family conflict (Karatepe and Kilic, 2007). Also, co-workers have an in-depth knowledge of the essence of the stressors available at the workplace. Thus, they have an excellent position to provide family-related support to their colleagues (Mesmer-Magnus and Viswesvaran, 2009). 


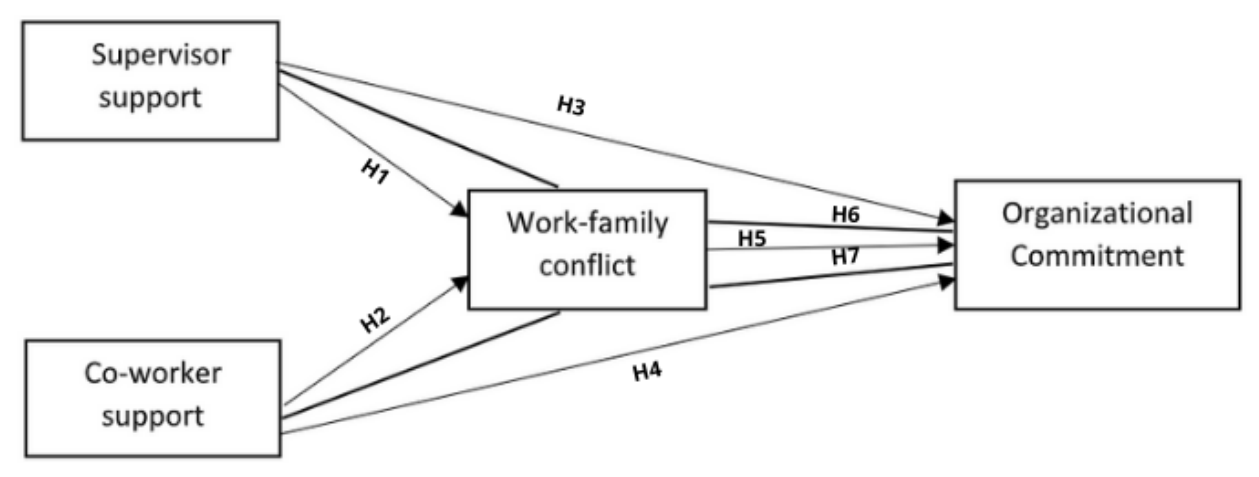

Figure 1. Conceptual framework

\subsubsection{Supervisor support and work-family conflict}

Supervisors who are sensitive towards the employees' needs and maintain balance among their work and family responsibilities are considered supportive by employees (Thomas and Ganster, 1995). The supportive supervisor works like an asset that helps in coping with the problem or issues that arises from work-family conflict (Karatepe and Kilic, 2007). The result of previous studies shows that actions adopted by the supervisors to help employees in meeting home duties may have an immense influence on resolving work-family conflict than the mere availability of formal human resource practices (Breaugh and Frye, 2008). Furthermore, supervisors can help employees through instrumental support like helping them manage their work hours or avail leaves when needed for family contingency (Bhargava and Baral, 2009). Supervisor support is related to lower levels of work-family conflict (Anderson et al., 2002; Goff et al., 1990). Thus, a significant difference can be made by supervisors if they cheer and support employees who need some specific policy for managing conflict (Chou and Cheung, 2013). When there are flexible arrangements and supportive supervisors, there is a positive and direct effect on employee perceptions of control over personal and professional matters, which leads to a reduction in work-family conflict (Thomas and Ganster, 1995). Showing empathy and letting them feel that their family responsibilities will not be ignored, a supportive supervisor can help build confidence and reduce the stress that results from work-family conflict (Bhargava and Baral, 2009). According to the results, work-family supervisor support was found to be negatively linked to work-family conflict (French et al., 2018; Talukder, 2019; Tran et al., 2021; Yeh et al., 2021; Sirin and Yücel, 2021).

Therefore, we may hypothesize that:

Hypothesis 1: Supervisor support has a negative effect on work-family conflict.

\subsubsection{Co-worker support and work-family conflict}

Co-worker support is defined as "the extent to which one's co-workers are helpful, can be relied upon in times of need, are receptive to work-related problems" (Menguc and Boichuk, 2012). The organization's rising teambased working system also offers co-workers the opportunity to provide instrumental and emotional help for their colleagues experiencing work-family conflict (Mesmer-Magnus and Viswesvaran, 2009). They are readily available to help each other in meeting work demands. Providing care and help in information sharing and tangible support are some forms of co-worker support (Ducharme and Martin, 2000). As co-workers do similar work or complementary tasks, they face similar conditions at work. Therefore, they are better positioned to provide problem-focused situation-associated support (Rousseau and Aubé, 2010). Work-family conflict can be reduced directly or by changing the effect of stressors through co-worker's support (Van Daalen et al., 2006). Co-workers could help in relieving home/work stress by offering suggestions, sharing information and resources. Valcour et al. (2011) concluded that assistance from co-workers would intensify the perception of support. When perceived support from colleagues for work-family balance increased, less work-life conflict was found (Korabik and Warner, 2013). Support from co-workers is a predictor of work-family conflict. Individuals who are married or parents had experienced more reduction in WFC as a result of co-worker support than nonmarried or non-parents, according to the findings (Michel et al., 2011).

Support from co-workers was linked to a more favourable work environment and lesser work-life conflict (Norling and Chopik, 2020). Contrary to this, a study performed on faculty members showed that colleague support did not significantly reduce work-family conflict. (Gopalan et al., 2020). 
Therefore, we may hypothesize that:

Hypothesis 2: Co-worker support has a negative effect on work-family conflict.

\subsubsection{Supervisor support and Organizational commitment}

Supervisor support builds a feeling of worthiness in the employee and encourages a strong relationship between the employee and the organization (Dhir and Dutta, 2020). When employees believe that they will receive support from their organization for their family needs, one way they will reciprocate is by developing a stronger attachment (commitment) to the organization (Allen, 2001). Employees will be more attached or committed to the organization if they perceive their supervisors to be competitive, motivating, and especially thoughtful as transformational leaders (Wang and Walumbwa, 2007). Many studies showed that supervisor support has a direct and positive effect on organizational commitment (Aryee et al., 1998; Casper et al., 2011; Grover and Crooker, 1995; Kang et al., 2015). According to the results, supervisor support can significantly predict the employee's affective commitment (Orgambidez and Almeida, 2020). Furthermore, literature also showed that employees' affective commitment could be increased through supervisor support using job satisfaction as a mediator (Mohamed and Ali, 2016; Wang, 2014; Woo and Chelladurai, 2012). Results revealed that supervisor support acts as a predictor of work-family enrichment, and then work-family enrichment acts as a predictor of organizational commitment(Bhargava and Baral, 2009; Baral and Bhargava, 2010; Wayne et al., 2006).

Therefore, we may hypothesize that:

Hypothesis 3: Supervisor support has a positive effect on organizational commitment.

\subsubsection{Support from co-workers and organizational commitment}

Co-worker's support is the extent of help offered by colleagues at work (Liao et al., 2004) in the form of care, tangible and informative support (Ducharme and Martin, 2000). Co-workers encourage one another by sharing information and offering assistance, which boosts their sense of belonging and commitment to the company Joiner and Bakalis (2006). As co-workers are on the same level of hierarchy and there is no authority relationship between them, therefore, such help is considered as informal support. Support from immediate co-workers can help individuals feel more at ease in the workplace by meeting their needs for esteem, approbation, and affiliation (Stinglhamber and Vandenberghe, 2003). Both immediate supervisors and co-workers can provide assistance that fosters pleasant work experiences and can lead people to feel emotionally connected to the company (Rousseau and Aubé, 2010). Employees also think that their quitting the organization will increase the burden on their coworkers, thus it would be against the norm of reciprocity, and they feel it as their duty to stay with the organization (Limpanitgul et al., 2014). Results revealed that co-workers support positively influences organizational commitment (Nordat et al., 2019; Rousseau and Aubé, 2010). Due to co-worker and supervisor support, trust builds in employees' minds, and then it manifests as organizational commitment (Yang et al., 2019). Results showed that there exists a significant relationship between co-worker support and the affective and normative component of organizational commitment (Limpanitgul et al., 2014).

Thus, can safely hypothesize that:

Hypothesis 4: Co-worker support has a positive effect on organizational commitment.

\subsubsection{Work-family conflict and Organizational commitment}

In the cases of faculty members, there is a significant negative relationship between work-family conflict and organizational commitment (Rehman and Waheed, 2012). Akintayo (2010) also showed that work-family conflict accounts for a significant amount of the total variance in organizational commitment. Therefore, the literature reveals that work-family conflict and organizational commitment are negatively related (Malik and Awan, 2015; Hatam et al., 2016; Jenitta and Periyathampy, 2013).

Therefore, we may hypothesize that:

Hypothesis 5: Work-family conflict has a negative effect on organizational commitment. 


\subsubsection{Work-family conflict as a mediator}

Many studies report that supervisor support influences work-family conflict (Anderson et al., 2002; Thomas and Ganster, 1995; Goff et al., 1990; Breaugh and Frye, 2008). Also, literature shows that co-worker support influences work-family conflict (Korabik and Warner, 2013; Van Daalen et al., 2006). Similarly, the work-family conflict influences organizational commitment (Hatam et al., 2016; Rehman and Waheed, 2012).

Therefore, we may hypothesize that:

Hypothesis 6: Work-family conflict mediates the relationship between supervisor support and organizational commitment.

Hypothesis 7: Work-family conflict mediates the relationship between co-worker support and organizational commitment.

\section{Research Methodology}

\subsection{Sample and Data collection}

Employees working in different service organizations such as telecommunication, banking, finance, information technology, business process outsourcing, hospitality, and healthcare located in Delhi-NCR were approached for primary data collection. Keeping in mind time and cost constraints, this study adopted convenience sampling for the survey. Such a sampling method serves best when it is not practically possible to know all the respondents. In order to conduct the survey at a large scale, both web-based and offline modes were used for data collection. Subsequently, 610 questionnaires were distributed for the study. Out of which, 382 questionnaires were received back. On further scrutiny, we found that only 353 participants entirely and correctly filled the questionnaires. The response rate was $57.86 \%$. Also, a cover letter was attached with the questionnaire to describe the purpose of the survey. It also mentioned data would be used for academic purposes only and with complete confidentiality.

\subsection{Measurement Scales}

The questionnaire was developed using the already established scales by past researchers. The first section of the questionnaire covered the necessary information about demographics like age of the respondent, educational qualification, gender, nature of the organization, work experience, and marital status. The second section collected information related to the main variables of the study. Support from supervisor was measured using a six-items adapted from (Anderson et al., 2002). A sample item was "My supervisor is supportive when I have a work problem." Statements related to co-worker support were adapted from (Ducharme and Martin, 2000). A sample item was "I feel comfortable discussing changes in my work schedules with my colleagues." Five work-family conflict statements were adapted from (Netemeyer et al., 1996). A sample item was "The demands of my work interfere with my home and family life." Statements related to organizational commitment were adapted from (Meyer and Allen, 1997). A sample item was "I would be very happy to spend the rest of my career with this organization." For all scales, the five-point Likert scale ranging from 1 (strongly disagree) to 5 (strongly agree) was used.

\subsection{Tools and Techniques}

Partial least square structural equational modelling (PLS-SEM) was applied to analyze the influence of supervisor and co-worker support and work-family conflict on employees' organizational commitment using Smart PLS (version 3.3.2) software. PLS-SEM is referred to as the second generation of multivariate technique and treated as an alternative to covariance-based options (Vinzi et al., 2010). PLS-SEM is used, as it can work well on small sample sizes and non-normal data (Hair et al., 2014). This technique has also become well established and recognized in several fields by various researchers (Hair et al., 2014). Moreover, limited sample size and initial conceptual development characterize the real-world truth of research in the social sciences, making it difficult to meet the standards of covariance-based SEM (Evermann and Tate, 2010). PLS-SEM uses all variance from the independent variable to check the variance in the dependent variable. Both confirmatory and exploratory research can be performed using PLS-SEM (Dhir and Dutta, 2020).

After checking the validity and reliability of the constructs using measurement model assessment, the relationship between different constructs was assessed through structural model assessment. Blindfolding was applied to assess the predictive relevance using $Q$ square. To check mediation, bootstrapping was used, and to check the size of mediation, the variance accounted for (VAF) was applied. 


\subsection{Common Method Bias}

Common method bias is common in questionnaire-based studies and self-report measures. As respondents themselves filled the data, there lies the possibility of common method bias. While collecting data, procedural integrity was given the needed attention. The purpose of the study was conveyed to the respondents, and participation in the survey was voluntary. Respondents were assured about non-disclosure of their identity. Respondents were briefly informed about available selection choices by mentioning that there were no correct or incorrect answers. The items of the questionnaire were brief and asked section-wise to break the monotony. To deal with the problem of common method bias, we adopted Harman's single factor method. All items were included in the Exploratory Factor Analysis, which was conducted using SPSS 20. The first component explained 39.61 percent of the variance, which is less than the 50\% (Podsakoff et al., 2003; Singh and Srivastava, 2021) As a result, common method bias was eliminated.

We have also used common latent factor (CLF) test. The standardised regression weights of all items were evaluated for models with and without CLF using the Common latent factor approach (CLF). The variations in these regression weights were found to be quite minor (less than 2.0), indicating that common method bias is not a significant concern in our data (Gaski, 2017; Archimi et al., 2018).

\section{Results and Analysis}

PLS-SEM has two steps assessment that is measurement model assessment and then structural model assessment. Firstly, the outer model is assessed, and then the inner model (relation between the construct).

\subsection{Measurement Model Assessments}

Convergent validity and internal reliability were applied to check outer model parameters (Shiva et al., 2020). For checking the reliability of the data, Cronbach alpha, CR, and rho A were used. Table 1 depicts that Cronbach alpha of all constructs had a value of more than .70, which is the minimum threshold limit (Hair et al., 2014, 2020) Likewise, rho A and CR values are more than the minimum limit of .70 (Hair Jr et al., 2019). Hence the reliability of the constructs was confirmed. AVE was used to see the convergent validity. All AVE scores were found more than the minimum threshold limit of .50 (Fornell and Larcker, 1981; Hair Jr et al., 2019). Thus, the convergent validity of the construct was confirmed, as shown in Table 1.

Fornell-Larcker criterion, 1981 as well as and new method HTMT, were used to check for the discriminant validity. According to the Fornell-Larcker criterion, under root of AVE of the construct on the diagonal should be more than inter-item correlations. All under roots of AVE of the constructs had a higher value than the inter-item correlations presented in Table 2.

According to the new Heterotrait-Monotrait ratio of correlation (HTMT) method, values should be less than .85 (Henseler et al., 2015; Voorhees et al., 2016). HTMT values of all constructs are smaller than .85, as shown in Table 3. Hence, both Fornell-Larcker criterion 1981 and HTMT showed that the discriminant validity of the model was acceptable.

\subsection{Structural Model Assesments}

Structural model assessment initiates with calculating the coefficient of determination (R2) for dependent construct in the model. R2 explains the amount of variance in the model. The value of R2 should be sufficiently high to have a minimum level of explanatory power. Our model describes $36.8 \%$ variance for organizational commitment (see Figure 2). Thus, the R2 value in this organizational commitment case is acceptable (Hair et al., 2014). All variance inflation factor (VIF) values range between 1.203 to 1.714, which are smaller than the limit provided. Threshold values of VIF should be near to 3.3 and lower (Kock and Lynn, 2012)). It depicts that model has no collinearity problem.

SRMR, a model fit index, is essential to report (Hair et al., 2020). SRMR value of the model is 0.044 , which is below the maximum limit of 0.08. Thus, it confirms model accuracy (Henseler et al., 2016). Another essential thing for predictive relevance is to assess Stone-Geisser Q2 (Hair et al., 2014). Limits provided for examining the change in R2 due to an independent variable's impact on the dependent variable are 0.02 for a small effect, 0.15 for moderate, and 0.35 for a large effect (Cohen, 1998). This study has a Q2 value of 0.252 for organizational commitment, representing moderate relevance, and 0.126 for work-family conflict, which shows small relevance (see Table 4). Hence, the independent constructs are significant, and the generalization of results is possible in different contexts in the future. Work-family conflict discloses a moderate effect size on organizational commitment with an F2 value of 0.163. Hence, Work-family conflict is most important in explaining the organizational commitment in this model. In contrast, supervisor support shows a weak effect size with an F2 value of 0.074 on organizational commitment. However, in the case of co-worker support, no effect size was found having F2 value of 0.015 only. Hence both Work-family conflict and supervisor support are essential in explaining the endogenous variable organizational commitment. 
Table 1. Results for the measurement model assessment

\begin{tabular}{|c|c|c|c|c|c|c|c|}
\hline Construct & Items & Type & Loadings & $\mathrm{CR}$ & Cronbach's alpha & Rho A & AVE \\
\hline \multirow[t]{6}{*}{ Supervisor Support } & SS1 & Reflective & 0.881 & 0.941 & 0.925 & 0.931 & 0.729 \\
\hline & $\mathrm{SS} 2$ & & 0.816 & & & & \\
\hline & SS3 & & 0.791 & & & & \\
\hline & $\mathrm{SS}_{4}$ & & 0.887 & & & & \\
\hline & SS5 & & 0.862 & & & & \\
\hline & SS6 & & 0.880 & & & & \\
\hline \multirow[t]{8}{*}{ Co-worker Support } & CWS1 & Reflective & 0.812 & 0.923 & 0.905 & 0.914 & 0.602 \\
\hline & CWS2 & & 0.815 & & & & \\
\hline & CWS3 & & 0.769 & & & & \\
\hline & CWS4 & & 0.806 & & & & \\
\hline & CWS5 & & 0.675 & & & & \\
\hline & CWS6 & & 0.782 & & & & \\
\hline & CWS7 & & 0.671 & & & & \\
\hline & CWS8 & & 0.855 & & & & \\
\hline \multirow[t]{5}{*}{ Work-family Conflict } & WFC1 & Reflective & 0.894 & 0.947 & 0.930 & 0.932 & 0.782 \\
\hline & WFC2 & & 0.886 & & & & \\
\hline & WFC3 & & 0.855 & & & & \\
\hline & WFC4 & & 0.862 & & & & \\
\hline & WFC5 & & 0.922 & & & & \\
\hline \multirow[t]{8}{*}{ Organizational Commitment } & OC1 & Reflective & 0.837 & 0.950 & 0.943 & 0.946 & 0.714 \\
\hline & $\mathrm{OC} 2$ & & 0.794 & & & & \\
\hline & OC3 & & 0.814 & & & & \\
\hline & OC4 & & 0.876 & & & & \\
\hline & $\mathrm{OC} 5$ & & 0.864 & & & & \\
\hline & OC6 & & 0.863 & & & & \\
\hline & OC7 & & 0.845 & & & & \\
\hline & OC8 & & 0.864 & & & & \\
\hline
\end{tabular}

Source: Research data

Note: $\mathrm{CR}=$ Composite reliability, $\mathrm{AVE}=$ Average variance extracted

Table 2. Discriminant validity of the constructs (Fornell-Larcker criterion)

\begin{tabular}{lllll}
\hline & CWS & OC & SS & WFC \\
\hline CWS & 0.776 & & & \\
OC & 0.408 & 0.845 & & \\
SS & 0.610 & 0.497 & 0.854 & \\
WFC & -0.323 & -0.504 & -0.398 & 0.884 \\
\hline
\end{tabular}

Source: Research data

Now, the structural model and hypothesis testing are represented in Table 5. For checking significance, bootstrapping with 5000 resamples was performed as suggested by (Hair et al., 2014). Table 5 presents the results of hypothesis testing. $\mathrm{H} 1, \mathrm{H} 2, \mathrm{H} 3, \mathrm{H} 4$, and $\mathrm{H} 5$ were related to the direct relationship between constructs. The significance of the path coefficients has been investigated using the $t$-value. Results indicate the level of significance for $\mathrm{H} 1, \mathrm{H} 3$ \& H5 except for H2 \& H4. Hence, results depict significant effect for supervisor support on work-family conflict (beta value $=-.319$ and $p$-value $=0$ ), supervisor support on organisational commitment $(B=0.282, p<0.05)$, and work-family conflict on organisational commitment (betavalue $=-0.352$ and $p-v a l u e=0$ ). Therefore, hypotheses 2 and 4 were not supported.

\subsection{Mediation analysis}

Table 6 represents the significance of the indirect effect using the bootstrapping method. Work-family conflict does not mediate the relation between support from co-workers and organizational commitment (beta value $=0.045$ and $\mathrm{t}$-value $=1.680$ ). Result reveals that work-family conflict mediates the relation between supervisor support and organizational commitment (beta value $=0.112$ and $t$-value $=3.863$ ). Hence, $\mathrm{H} 6$ is Supported but not $\mathrm{H} 7$. As per Hair et al. (2014), to check the size of mediation, calculation of VAF is done (see Table 7). When the calculated value of VAF is less than 0.20 , then there exists no mediation; if VAF lies between 0.2 to 0.8 , it is a partial mediation case, and where the VAF value is higher than 0.8 , then it depicts full mediation. In this study value of VAF is .291 (see Table 7), which lies between 0.2 to 0.8 . hence it is partial mediation. 
Table 3. Discriminant validity assessment of the constructs (HTMT)

\begin{tabular}{lllll}
\hline & CWS & OC & SS & WFC \\
\hline CWS & & & & \\
OC & 0.437 & & & \\
SS & 0.657 & 0.526 & & \\
WFC & 0.345 & 0.534 & 0.425 & \\
\hline
\end{tabular}

Source: Research data

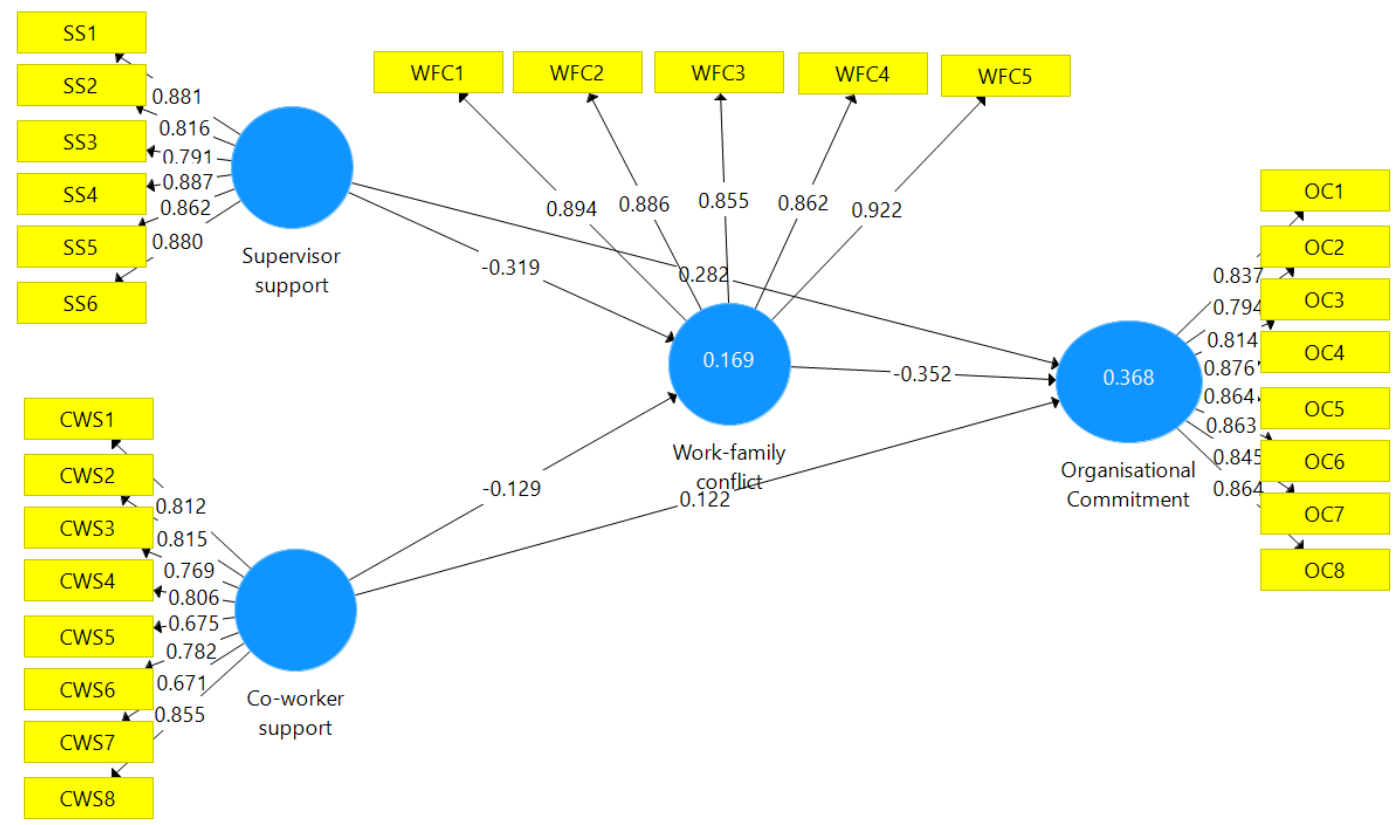

Figure 2. Structural path model

\section{Discussion}

The main purpose of this study was to explore the following research questions, whether (1) Supervisor support helps in improving organizational commitment, (2) Co-worker support helps in improving organizational commitment and (3) Work-family conflict mediates the relationship between supervisor support, co-worker support, and organizational commitment. The findings demonstrate that while supervisor support helps in improving organisational commitment but co-worker support does not significantly influence organisational commitment. Mediation result shows that work-family conflict mediates the relationship between supervisor support and organisational commitment but again it does not mediate the relationship between co-worker support and organisational commitment. Hence, the results indicates that supervisor support is more important in influencing organisational commitment. However, co-worker support also has negative influence on work-family conflict and positively influence organisational commitment but it does not have significant effect.

Results confirms that supervisor support could make the employee feel comfortable and attached to the organization by reducing work-family conflict. Thus, an organization can have more dedicated and committed employees using support from supervisor. Hence supervisor support plays a vital role in increasing the organizational commitment in service sector employees as compared to co-worker support. Our study results are consistent with the previous research in the western context, which shows that supervisor support positively influences organizational commitment (Aryee et al., 1998; Dhir and Dutta, 2020; Kang et al., 2015; Mohamed and Ali, 2016; Wang, 2014; Wang and Walumbwa, 2007). Also, the finding that supervisor support negatively influences work-family conflict is accordant with the results of the earlier studies (Lapierre and Allen, 2006; Anderson et al., 2002; Karatepe and Kilic, 2007; Breaugh and Frye, 2008).

Thus, organizations should inculcate a culture where the employees can garner work-life support with their supervisors' help. Motivating managers to maintain good quality exchange relationships with employees under their supervision can significantly support subordinates (Major and Lauzun, 2010). Managers should be well familiar with and be able to comprehend the situation of their employees and support them to balance their personal and professional goals (O'Driscoll et al., 2003). Managers are in a good position to convince top management to frame better policies according to the actual need of their subordinates (Kumar et al., 2019). 
Table 4. Coefficient of determination $\left(R^{2}\right)$ and $Q^{2}$

\begin{tabular}{llcl}
\hline Endogenous Variable & R Square & Adjusted R Square & Q Square \\
\hline Organizational Commitment & 0.368 & 0.362 & 0.252 \\
Work-family Conflict & 0.169 & 0.164 & 0.126 \\
\hline
\end{tabular}

Source: Research data

Table 5. Structural Model Assessments (Direct effect)

\begin{tabular}{llccccl}
\hline Hypothesis & Path Relationships & Std. Beta & Sample Mean $(M)$ & t-values & P-value & Decisions \\
\hline H1 & SS ->WFC & -0.319 & -0.321 & 4.937 & 0.000 & Supported \\
H2 & CWS ->WFC & -0.129 & -0.131 & 1.789 & 0.076 & Not supported \\
H3 & SS -> OC & 0.282 & 0.281 & 4.182 & 0.000 & Supported \\
H4 & CWS ->OC & 0.122 & 0.126 & 1.924 & 0.059 & Not supported \\
H5 & WFC -> OC & -0.352 & -0.353 & 6.179 & 0.000 & Supported \\
\hline
\end{tabular}

Source: Research data

\section{Conclusion}

Our study provides a more comprehensive and in-depth examination of the relationship between supervisor support, co-workers support and organizational commitment. Our result shows that supervisor support at the workplace for family get reciprocated through more organizational commitment and lesser work-family conflict. Hence, management should put maximum effort to encourage the supervisors to extend their support to create a much more friendly environment at the workplace to reduce work-family conflict and enhance commitment. Result suggests that special attention should be paid while hiring and recruiting managers and employees as they can help in building a loyal and committed workforce for the organization that ultimately enhances productivity. Also, the organization can encourage and provide training to the supervisors so as to enable them to empathetically understand the importance of the role of the supervisor.

This study authenticates the significance of supervisor support in influencing employee's organizational commitment using work-family conflict as a mediator in a developing economy like India. In a collectivistic country like India, where family is given equal importance, such results become more useful.

\section{Implications}

The supervisor can act as an initiator to determine if any of his employees are experiencing work-family conflict and can provide counselling to resolve such problems immediately. Such an organization will be promoted as a familysupportive organization, and it will have the potential to attract and retain a talented pool of employees. Also, supervisor support may help gain outcomes such as organizational performance, loyalty, and satisfaction at the job. The organization can focus on proper training of managers to have special skills for negotiating several roles of employees (Mukanzi and Senaji, 2015). Such assistance will aid supervisors in developing effective communication with their employees and developing favourable employee outcomes. When there is more support for the family at the workplace, then there will be less absenteeism, low poor performance and reduced employee turnover cost for the organization. Employees will feel encouraged to use family-friendly programmes. When employees are more committed to the organization due to the support provided by supervisors, then the productivity of the organization will automatically increase. When employees are able to effectively deal with their family responsibilities, then they will contend at both personal and professional fronts. In this regard, care and concern for employees' children and elderly parents by the organizations will boost their happiness. Notably, there would be fewer chances of stress, anxiety and depression. Both family satisfaction and job satisfaction will grow simultaneously, which will enhance the overall quality of life of employees. As a result, there will be lesser cases of violence and mental health issues. Ultimately the whole society will get benefitted due to a dedicated workforce and higher productivity as organizations are a subset of a society only.

\section{Limitations and Future Directions for Study}

This study is cross-sectional. Therefore, longitudinal studies can be performed to draw causal inferences (Khan and Zaman, 2020). Our study may help researchers to further explore it by including other variables such as family-friendly policies and other job outcomes such as motivation, job satisfaction and performance, etc. 
Table 6. Indirect effect results

\begin{tabular}{lllllll}
\hline Hypothesis & Path Relationships & St. Beta & Sample Mean $(M)$ & t-values & P value & Decisions \\
\hline H6 & SS ->WFC ->OC & 0.112 & 0.113 & 3.863 & 0.000 & Supported \\
H7 & CWS ->WFC ->OC & 0.045 & 0.046 & 1.68 & 0.096 & Not supported \\
\hline
\end{tabular}

Source: Research data

Table 7. Results of the mediation analysis (VAF)

\begin{tabular}{llllll}
\hline Exogenous Variable & Direct Effect & Indirect Effect & Total Effect & VAF & Mediation \\
\hline Supervisor Support & 0.352 & 0.1448 & 0.496 & 0.291 & Partial \\
\hline
\end{tabular}

Source: Research data

\section{References}

Aboobaker, N., Edward, M., 2019. The collective influence of work-family conflict and work-family enrichment on turnover intention: Exploring the moderating effects of individual differences. Global Business Review 21(5), 1218-1231. URL: https://doi.org/10.1177/0972150919857015.

Afshar Jahanshahi, A., Adiguzel, Z., Sonmez Cakir, F., 2020. Managerial support for innovation as the source of corporate sustainability and innovative performance: Empirical evidence from turkey. Journal of Public Affairs URL: https://doi.org/10.1002/pa.2428.

Akintayo, D.I., 2010. Work-family role conflict and organizational commitment among industrial workers in nigeria. Journal of Psychology and Counselling 2(1), 1-8. URL: https://doi.org/10.5897/IJPC.9000064.

Allen, T.D., 2001. Family-supportive work environments: The role of organizational perceptions. Journal of Vocational Behaviour 58(3), 414-435. URL: https://doi.org/10.1006/jvbe.2000.1774.

Anderson, S.E., Coffey, B.S., Byerly, R.T., 2002. Formal organizational initiatives and informal workplace practices: Links to work-family conflict and job-related outcomes. Journal of Management 28(6), 787-810. URL: https: //doi.org/10.1177/014920630202800605.

Archimi, C.S., Reynaud, E., Yasin, H.M., Bhatti, Z.A., 2018. How perceived corporate social responsibility affects employee cynicism: The mediating role of organizational trust. Journal of Business Ethics 151(4), 907-921.

Aryee, S., Luk, V., Stone, R., 1998. Family-responsive variables and retention-relevant outcomes among employed parents. Human Relations 51(1), 73-87. URL: https://doi.org/10.1023/A:101695390821.

Bakhshi, A., Sharma, A.D., Kumar, K., 2011. Organizational commitment as a predictor of organizational citizenship behaviour. European Journal of Business and Management 3(4), 78-86.

Baral, R., Bhargava, S., 2010. Work-family enrichment as a mediator between organizational interventions for work-life balance and job outcomes. Journal of Managerial Psychology URL: doi.org/10.1108/02683941011023749.

Bhargava, S., Baral, R., 2009. Antecedents and consequences of work-family enrichment among indian managers. Psychological Studies 54(3), 213. URL: https://doi.org/10.1007/s12646-009-0028-z.

Breaugh, J.A., Frye, N.K., 2008. Work-family conflict: The importance of family-friendly employment practices and family-supportive supervisors. Journal of Business and Psychology 22(4), 345-353. URL: https://doi.org/ 10.1007/s10869-008-9081-1.

Carlson, D.S., Perrewé, P.L., 1999. The role of social support in the stressor-strain relationship: An examination of work-family conflict. Journal of Management 25(4), 513-540. URL: https://doi.org/10.1016/S0149-2063(99) 00013-6.

Casper, W.J., Harris, C., Taylor-Bianco, A., Wayne, J.H., 2011. Work-family conflict perceived supervisor support and organizational commitment among brazilian professionals. Journal of Vocational Behavior 79(3), 640-652. URL: https://doi.org/doi:10.1016/j.jvb.2011.04.011.

Chandra, V., 2010. Women and work-family interface: Indian context. Journal of Asia Pacific Studies 1(2), 235-258.

Chou, K.L., Cheung, K.C.K., 2013. Family-friendly policies in the workplace and their effect on work-life conflicts in hong kong. The International Journal of Human Resource Management 24(20), 3872-3885. URL: https: //doi.org/10.1080/09585192.2013.781529.

Cohen, J., 1998. Statistical power analysis for the behavioral sciences 2nd edition. NJ : Lawrence Erlbaum Associates, Hills dale.

Dhir, S., Dutta, T., 2020. Linking supervisor-support, person-job fit and person- organization fit to company value. Journal of Indian Business Research 12(4), 549-561. URL: https://doi .org/10.1108/JIBR-04-2019-0124.

Ducharme, L.J., Martin, J.K., 2000. Unrewarding work, co-worker supportand job satisfaction: A test of the buffering hypothesis. Work and Occupations 27(2), 223-243. URL: https://doi.org/10.1177/0730888400027002005.

Evermann, J., Tate, M., 2010. Testing models or fitting models? identifying model misspecification in PLS. ICIS , 21.

Fornell, C., Larcker, D.F., 1981. Evaluating structural equation models with unobservable variables and measurement error. Journal of Marketing Research 18(1), 39-50. URL: https://doi.org/10.1177/002224378101800104.

French, K.A., Dumani, S., Allen, T.D., Shockley, K.M., 2018. A meta-analysis of work-family conflict and social 
support. Psychological Bulletin 144(3), 284-314. URL: https://doi.org/10.1037/bu10000120.

Gaski, J., 2017. Confirmatory factory analysis. URL: http://statwiki.kolobkreations.com/index.php?title= Confirmatory_FactorAnalysis\&redirect=no\#Common_Latent_Factor. 15-03-2018.

Goff, S.J., Mount, M.K., Jamison, R.L., 1990. Employer supported child care, work/family conflictand absenteeism: A field study. Personnel Psychology 43(4), 793-809. URL: https://doi.org/10.1111/j.1744-6570.1990.tb00683.x.

Gopalan, N., Pattusamy, M., Gollakota, K., 2020. Role of support in work-family interface among university faculty in India. South Asian Journal of Business Studies 9(3), 323-338. URL: https://doi.org/10.1108/ SAJBS-11-2019-0211.

Greenhaus, J.H., Parasuraman, S., 1994. Work-family conflict, social support and well- being. Women in Management: Current Research Issues 9(3), 213-229. URL: https://doi.org/10.1108/SAJBS-11-2019-0211.

Grover, S.L., Crooker, K.J., 1995. Who appreciates family-responsive human resource policies: The impact of family-friendly policies on the organizational attachment of parents and non-parents? Personnel psychology 48(2), 271-288. URL: https://doi.org/10.1111/j.1744-6570.1995.tb01757.x.

Gutek, B.A., Searle, S., Klepa, L., 1991. Rational versus gender role explanations for work- family conflict. Journal of Applied Psychology 76(4), 560-568.

Hair, J.F., Howard, M.C., Nitzl, C., 2020. Assessing measurement model quality in pls-sem using confirmatory composite analysis. Journal of Business Research 109, 101-110. URL: https://doi .org/10.1016/j.jbusres.2019.11. 069.

Hair, J.F., Hult, G.T.M., Ringle, C., Sarstedt, M., 2014. A primer on partial least squares structural equation modelling (PLS-SEM) (2nd ed). CA: SAGE Publications, Thousand Oaks.

Hair Jr, J.F., Howard, M.C., Nitzl, C., 2019. Rethinking some of the rethinking of partial least squares. European Journal of Marketing 53(4), 566-584. URL: https://doi.org/doi:10.1108/EJM-10-2018-0665.

Hammer, L.B., Kossek, E.E., Yragui, N.L., Bodner, T.E., Hanson, G.C., 2009. Development and validation of a multidimensional measure of family-supportive supervisor behaviors. Journal of Management 35(4), 837-856. URL: https://doi .org/10.1177/0149206308328510.

Hatam, N., Jalali, M.T., Askarian, M., Kharazmi, E., 2016. Relationship between family- work and workfamily conflict with organizational commitment and desertion intention among nurses and paramedical staff at hospitals. International Journal of Community-Based Nursing and Midwifery 4(2), 107-118. URL: https: //doi.org/10.1108/SAJBS-11-2019-0211.

Henseler, J., Ringle, C.M., Sarstedt, M., 2015. A new criterion for assessing discriminant validity in variancebased structural equation modelling. Journal of the Academy of Marketing Science 43(1), 115-135. URL: https: //doi.org/doi:10.1007/s11747-014-0403-8.

Henseler, J., Ringle, C.M., Sarstedt, M., 2016. Using pls path modeling in new technology research: updated guidelines. Industrial Management Data Systems 116, 1-19.

Hobfoll, S.E., Shirom, A., Golembiewski, R., 2000. Handbook of Organizational Behavior. volume 116. Marcel Dekker, New York.

Jenitta, J., Periyathampy, E., 2013. An impact of work-family conflict on organizational commitment: A study of staff members at people's bank in trincomalee district. International Journal of Research in Commerce Management 4(11), 122-125. URL: https://doi .org/doi:10.1007/s11747-014-0403-8.

Joiner, T.A., Bakalis, S., 2006. The antecedents of organizational commitment: the case of australian casual academics. International journal of Educational Management 20(6), 439-452. URL: https://doi.org/10.1108/ 09513540610683694.

Kang, H.J., Gatling, A., Kim, J., 2015. The impact of supervisory support on organizational commitment, career satisfactionand turnover intention for hospitality frontline employees. Journal of Human Resources in Hospitality \& Tourism 14(1), 68-89. URL: https://doi.org/10.1080/15332845.2014.904176.

Karatepe, O.M., Kilic, H., 2007. Relationships of supervisor support and conflicts in the work-family interface with the selected job outcomes of front line employees. Tourism Management 28(1), 238-252. URL: https: //doi.org/10.1016/j.tourman.2005.12.019.

Khan, M.N., Zaman, U., 2020. The effect of knowledge management practices on organizational innovation: Moderating role of management support. Journal of Public Affairs .

Kock, N., Lynn, G., 2012. Lateral collinearity and misleading results in variance- based sem: An illustration and recommendations. Journal of the Association for Information Systems 13(7).

Korabik, K., Warner, M., 2013. Expanding the Boundaries of Work-Family Research. volume 14(11). Palgrave Macmillan, London. URL: https://doi.org/10.1057/978113700600412.

Kumar, A., Ali Arain, G., Ahmed Channa, K., 2019. Relationship between organizational injustice and work interference with family: the role of social support. South Asian Journal of Human Resources Management 6(2), $129-155$. URL: https://doi.org/10.1177/2322093719828889.

Kushwaha, B.P., Tyagi, V., Sharma, P.B., Singh, R.K., 2020. Mediating role of growth needs and job satisfaction on talent sustainability in bpos and call centres: Evidence from india. . Journal of Public Affairs URL: https: //doi.org/10.1002/pa.2400.

Lapierre, L.M., Allen, T.D., 2006. Work-supportive family, family-supportive supervision, use of organizational benefitsand problem-focused coping: Implications for work-family conflict and employee well-being. Journal 
of Occupational Health Psychology 11, 169-181. URL: https://doi.org/10.1037/10768998.11.2.169.

Liao, H., Joshi, A., Chuang, A., 2004. Sticking out like a sore thumb: Employee dissimilarity and deviance at work. Personnel Psychology 57(4), 969-1000. URL: https://doi.org/doi:10.1007/s11747-014-0403-8.

Limpanitgul, T., Boonchoo, P., Photiyarach, S., 2014. Co-worker support and organizational commitment: A comparative study of thai employees working in thai and american airlines. Journal of Hospitality and Tourism Management 21, 100-107. URL: https://doi.org/10.1016/j.jhtm.2014.08.002.

Madhavi, C., 2015. Impact of work-family conflict on job and life satisfaction. International Journal on Global Business Management Research 3(2), 35-45.

Major, D.A., Lauzun, H.M., 2010. Equipping managers to assist employees in addressing work-family conflict: Applying the research literature toward innovative practice. The Psychologist Manager Journal 13(2), 69-85. URL: https://doi.org/10.1080/10887151003761275.

Malik, M.S., Awan, A.G., 2015. Role of work-family conflict on organizational commitment and organizational effectiveness. Nigerian Chapter of Arabian Journal of Business and Management Review 3(1), 115-126. URL: https://doi.org/10.12816/0011653.

Menguc, B., Boichuk, J.P., 2012. Customer orientation dissimilarity, sales unit identificationand customer-directed extra-role behaviors: Understanding the contingency role of co-worker support. Journal of Business Research 65(9), 1357- 1363. URL: https://doi.org/10.1016/j.jbusres.2011.09.023.

Mesmer-Magnus, J., Viswesvaran, C., 2009. The role of the co-worker in reducing work- family conflict: A review and directions for future research. Pratiques Psychologiques 15(2), 213-224. URL: https://doi.org/10.1016/j. prps.2008.09.009.

Meyer, J.P., Allen, N.J., 1997. Commitment in the workplace: Theory, research and application. Sage Publications.

Michel, J.S., Kotrba, L.M., Mitchelson, J.K., Clark, M.A., Baltes, B.B., 2011. Antecedents of work-family conflict: A meta-analytic review. Journal of Organizational Behavior 32(5), 689-725. URL: https://doi.org/10.1002/job.695.

Mohamed, S.A., Ali, M., 2016. The importance of supervisor support for employees' affective commitment: An analysis of job satisfaction. International Journal of Scientific and Research Publications 6(2), 435-439.

Mukanzi, C.M., Senaji, T.A., 2015. Work-family conflict and employee commitment: The moderating effect of perceived managerial support. SAGE Open 7(3), 1-12. URL: https://doi.org/10.1177/2158244017725794.

Murtza, M.H., Gill, S.A., Aslam, H.D., Noor, A., 2020. Intelligence quotient, job satisfactionand job performance: The moderating role of personality type. Journal of Public Affairs .

Netemeyer, R.G., Boles, J.S., McMurrian, R., 1996. Development and validation of work-family conflict and familywork conflict scales. Journal of Applied Psychology 81(4), 400-410. URL: https://doi .org/10.1037/0021-9010.81. 4.400 .

Nordat, I., Tola, B., Yasin, M., 2019. Impact work motivation and perceived co-worker support on organizational commitment at human resources development and management agency. URL: http://ejournal.aibpm.org/index. $\mathrm{php} / \mathrm{JICP} / \mathrm{article/view/650.}$

Norling, L.R., Chopik, W.J., 2020. The association between co-worker support and work- family interference: a test of work environment and burnout as mediators. Frontiers in Psychology 11, 981. URL: https://doi.org/10. 3389/fpsyg. 2020.00819.

O'Driscoll, M.P., Poelmans, S., Spector, P. E. andKalliath, T., Allen, T.D., Cooper, C.L., Sanchez, J.I., 2003. Familyresponsive interventions, perceived organizational and supervisor support, work-family conflictand psychological strain. International Journal of Stress Management 10(4), 326-344. URL: https://doi.org/10.1037/1072-5245. 10.4.326.

Orgambidez, A., Almeida, H., 2020. Supervisor support and affective organizational commitment: The mediator role of work engagement. Western Journal of Nursing Research 43(2), 187-193. URL: https://doi.org/10.1177/ 0193945919852426.

Panda, A., Jain, N.K., Nambudiri, R., 2021. Work-family conflict, affective commitment, leadership and job satisfaction: a moderated mediation analysis. International Journal of Productivity and Performance Management URL: https://doi.org/10.1108/IJPPM-01-2020-0040.

Podsakoff, P.M., MacKenzie, S.B., Lee, J.Y., Podsakoff, N.P., 2003. Common method biases in behavioral research: A critical review of the literature and recommended remedies. Journal of Applied Psychology 88(5), 879-903. URL: https://doi.org/10.1037/0021-9010.88.5.879.

Pradhan, R.K., Jena, L.K., Kumari, I.G., 2016. Effect of work-life balance on organizational citizenship behaviour: Role of organizational commitment. Global Business Review , 17(3), 115-135. URL: https://doi.org/10.1177/ 0972150916631071.

Rehman, R.R., Waheed, A., 2012. Work-family conflict and organizational commitment: a study of faculty members in pakistani universities. Pakistan Journal of Social \& Clinical Psychology 10(1).

Rousseau, V., Aubé, C., 2010. Social support at work and affective commitment to the organization: The moderating effect of job resource adequacy and ambient conditions. The Journal of Social Psychology 150(4 ), 321-340. URL: https://doi.org/10.1080/00224540903365380.

Sadiq, M., 2020. Policing in pandemic: Is the perception of workload causing work-family conflict, job dissatisfaction and job stress? Journal of Public Affairs 43(1). URL: https://doi.org/10.1002/pa.2486.

Shiva, A., Narula, S., Shahi, S.K., 2020. What drives retail investors' investment decisions? evidence from no 
mobile phone phobia (nomophobia) and investor fear of missing out(i-fomo). Journal of Content, Community Communication. 11(6), 2-21. URL: https://doi.org/10.31620/JCCC.06.20/02.

Singh, L.B., Srivastava, S., 2021. Linking workplace ostracism to turnover intention: A moderated mediation approach. Journal of Hospitality and Tourism Management 46, 244-256. URL: https://doi.org/10.1016/j.jhtm. 2020.12.012.

Sirin, M.S., Yücel, , 2021. The relationship between supervisor support and work-family conflict and the mediating role of work overload perception on this relationship. Ekonomski Vjesnik 34(1), 145-159. URL: https://doi.org/ $10.51680 /$ ev.34.1.11.

Stinglhamber, F., Vandenberghe, C., 2003. Organizations and supervisors as sources of support and targets of commitment: A longitudinal study. Journal of Organizational Behavior: The International Journal of Industrial, Occupational and Organizational Psychology and Behavior 24(3), 251-270. URL: https://doi.org/10.1002/job.192.

Talukder, A.M.H., 2019. Supervisor support and organizational commitment: the role of work-family conflict, job satisfactionand work-life balance. Journal of Employment Counseling 56(3), 98-116. URL: https://doi.org/10. 1002/joec. 12125.

Thomas, L.T., Ganster, D.C., 1995. Impact of family-supportive work variables on work- family conflict and strain: A control perspective. Journal of Applied Psychology 80(1), 6-15. URL: https://doi.org/10.1037/0021-9010.80.1.6.

Tran, P.A., Mansoor, S., Ali, M., 2021. Managerial support, work-family conflict and employee outcomes: an australian study. European Journal of Management and Business Economics 34(1), 145-159. URL: https://doi. org/10.1108/EJMBE-03-2020-0056.

Valcour, M., Ollier-Malaterre, A., Matz-Costa, C., Pitt-Catsouphes, M., Brown, M., 2011. Influences on employee perceptions of organizational work-life support: Signals and resources. Journal of Vocational Behavior 79(2), 588-595. URL: https://doi.org/10.1016/j.jvb.2011.02.002.

Van Daalen, G., Willemsen, T.M., Sanders, K., 2006. Reducing work-family conflict through different sources of social support. Journal of Vocational Behavior 69(3), 462-476. URL: https://doi.org/10.1016/j.jvb.2006.07.005.

Vinzi, V.E., Trinchera, L., Amato, S., 2010. PLS path modeling: from foundations to recent developments and open issues for model assessment and improvement. Springer, Berlin, Heidelberg.

Voorhees, C.M., Brady, M.K., Calantone, R., Ramirez, E., 2016. Discriminant validity testing in marketing: an analysis, causes for concernand proposed remedies. Journal of the Academy of Marketing Science 44(1), 119-134. URL: https://doi.org/10.1007/s11747-015-04554.

Wang, P., Walumbwa, F.O., 2007. Family-friendly programs, organizational commitment, and work withdrawal: the moderating role of transformational leadership. Personnel Psychology 60(2), 397-427. URL: https://doi. org $/ 10.1111 / j .1744-6570.2007 .00078 . x$.

Wang, Z., 2014. Perceived supervisor support and organizational citizenship behaviour: The role of organizational commitment. International Journal of Business and Social Science 5(1), 210-214.

Wayne, J.H., Randel, A.E., Stevens, J., 2006. The role of identity and work-family support in work-family enrichment and its work-related consequences. Journal of Vocational Behavior 69(3), 445-461. URL: https: //doi.org/10.1016/j.jvb.2006.07.002.

Woo, B., Chelladurai, P., 2012. Dynamics of perceived support and work attitudes: The case of fitness club employees. Human Resource Management Research 2(1), 6-18. URL: https://doi.org/10.5923/j.hrmr.20120201.02.

Yang, T., Ma, T., Liu, P., Liu, Y., Chen, Q., Guo, Y., ..., Deng, J., 2019. Perceived social support and presenteeism among healthcare workers in china: the mediating role of organizational commitment. Environmental Health and Preventive Medicine 24(1), 1-9. URL: https://doi.org/10.1186/s12199-019-0814-8.

Yeh, T.F., Chang, Y.C., Hsu, Y.H., Huang, L.L., Yang, C.C., 2021. Causes of nursing staff burnout: Exploring the effects of emotional exhaustion, work-family conflictand supervisor support. Japan Journal of Nursing Science 18(2). URL: https://doi.org/10.1111/jjns.12392.

Zeinabadi, H., 2021. Job satisfaction and organizational commitment as antecedents of organizational citizenship behavior (OCB) of teachers. Procedia-Social and Behavioral Sciences 5, 998-1003. URL: https://doi.org/10.1016/ j.sbspro.2010.07.225. 